Вісник Львівського університету. Серія філос.-політолог. студіi. 2020. Випуск 30, с. 47-54

Visnuk of the Lviv University. Series Philos.-Political Studies. Issue 30, p. 47-54

UDC 1.27-31

DOI https://doi.org/10.30970/PPS.2020.30.6

\title{
CANONICAL PRINCIPLE OF AUTOCEPHALY IN THE RESOLUTIONS OF ECUMENICAL COUNCILS
}

\author{
Andriy Kobetyak \\ Zhytomyr Ivan Franko State University, \\ Department of Philosophy and Political Science \\ Velyka Berdychivska str., 40, 10008, Zhytomyr, Ukraine
}

The article analyzes the influence of the Ecumenical Councils on the historical and legal aspects of the proclamation of autocephaly and the autonomy of the church as an object of study. It is established that in the pre-conciliar period the teachings of Christ and the apostles were transmitted mainly through the sermons of the holy fathers. The lack of a fixed canon and dogma gave rise to the first theological debates on attitudes toward the Church, the Scriptures, and Christian teaching. It is proved that it was during the Ecumenical Councils that all the dogmatic and canonical works of the early church were framed in specific rules in the form of Council resolutions.

We believe that the Ecumenical Council was the reaction of the whole church to a problem that the church community had not encountered before. It is a panacea to heal a particular wound on the church body that has manifested itself in bias or a distorted interpretation of certain passages of Scripture. Fathers and representatives of all the then Local Churches gathered together to resolve the problem that troubled the church. It is established that during this period the autocephalous principle of the existence of individual churches, which was borrowed from the Byzantine-Roman Empire, was finally enshrined in the resolutions of several Second and Fourth Ecumenical Councils. It has been proven that the highest level of church organization is the ancient patriarchates, which united several metropolitanates. A "pentarchy" is being formed, the theory of the management of the Ecumenical Church by the five most influential departments. Such a structure of administrative-church division in the structure of the Ecumenical Church is preserved today. Each of the Local Churches, regardless of its status, is independent and autonomous in its own inner life.

We believe that the example of resolving church disputes and combating church divisions during the Ecumenical Councils should be used by modern hierarchs. Today the Ecumenical Church is on the verge of a great schism. Several local churches broke off the Eucharistic communion, which symbolizes common unity. Therefore, further detailed research of the Nicaea period and the institutionalization of the autocephalous church system of that time will serve to establish a tolerant dialogue between the hierarchs of the Local Churches in the XXI century. influence.

Key words: Ecumenical Council, patriarchy, diptych, autocephaly, canon, metropolitan, political

The crisis of Ecumenical Orthodoxy, which became clear after the Great Council of Crete in 2016, negatively affected the intra-church life of most Local Churches. The next event of world importance, which became the dividing line in the Ecumenical Church, was the proclamation of the autocephaly of the Ukrainian Church, which took 15th place in the diptych. Due to the lack of a unified and generally agreed mechanism for the proclamation of a new autocephalous church (The document "Autocephaly and methods of its proclamation" was to be adopted at the Council of Crete, which was not attended by representatives of the four Local Churches), the hierarchs of world churches have radically opposite approaches to the non/recognition of the Orthodox Church of Ukraine as their sister church. Discussions about the primacy and powers of the Ecu-

(C) A. Kobetyak, 2020 
menical Throne, including the issue of granting autocephalous status, have always taken place in church history. However, they became especially acute in connection with the declaration of independence of the next Local Church (Such events took place due to the granting of autocephaly to the Bulgarian OC, the Polish OC, the Church of the Czech Lands and Slovakia, and others). And the theological discussion is connected with the formation of diptychs and the prerogative of granting autocephalous status (conciliar, from the Mother Church or the Patriarch of Constantinople) in connection with the proclamation of independence of the Ukrainian Church. Thus, the surrounding autocephalous issues are not new. This problem has repeatedly seriously exacerbated relations between the Local Churches. Several national churches, such as the Montenegrin and Macedonian, are still awaiting universal recognition. Therefore, the issue of autocephaly of the new Local Church on a universal scale is extremely relevant today.

All modern church life, as well as the very principles of Christ's existence, was finally fixed during the Ecumenical Councils, when the canon of Scripture was clearly formed, church dogmas, which the church uses today, and regulated major issues of church life and organization. All the church teachings of the early period are certainly relevant today, because the highest body of church government is the Ecumenical Council. Thus, the study of the problem of autocephalous formation of the first ancient patriarchates during the Ecumenical Councils is not just relevant, but basic for any autocephalous discussions. After all, the resolutions and rules of the Ecumenical Councils are binding and have no statute of limitations. Thus, for a scientific discussion on the possibility of autocephaly in the XXI century, it is necessary to study the problem of church independence in the rules of the Councils.

The state of scientific development of the chosen topic is patchy. On the one hand, there are numerous scientific, both secular and ecclesiastical, studies of the decisions of the Ecumenical Councils and the historical epoch in the formation of Christianity in general. Unequivocally, this is the "golden", the fundamental period of formation of church life. On the other hand, autocephalous issues have been little studied, because in the period of IV-VIII centuries it was not acute. Five ancient patriarchates were clearly formed, which governed the life of the Ecumenical Church. That is, there is a lot of research on cathedral art, but the selection of material on the research topic is meager.

Among the important sources of research are the numerous statements and official appeals of most modern hierarchs and theologians who try to appeal to canons and rules, but there are radically opposite interpretations of the same position depending on the position of the Local Church.

Valuable today are the works of researchers of Ukrainian church history and the canonical structure of the Orthodox Church I. Vlasovsky, O. Kyridon, O. Lototsky, Y. Mulyk-Lutsyk and others, who repeatedly drew attention to the period of canonical church creativity of Christianity and the formation of the institution of autocephaly. Among the scholars who studied the Conciliar period of the formation of Christian dogmas, it is necessary to single out world-renowned researchers of church history: V. Asmus, A. von Harnack, J. Robertson, A. Kartashev, E. Caesarea, N. Milash, E. Smirnov, S. Smirnov, K. Skurat, F. Uspensky and many others. The works of the mentioned authors reveal the main periods of development and objective-situational conditionality of the autocephalous principle of the church's existence. The scientific work of the world-famous theologian Archimandrite Kirill (Govorun) is a thorough scientific work. In particular, a dissertation on ecclesiology, in which much attention is paid to the period of the Ecumenical Councils and the problem of autocephaly. A fundamental study of the period chosen for study is V. Bolotov's four-volume book on the history of the ancient Church, which gradually reveals the external church growth of the parish network and the internal structure of Orthodoxy 
of that time. In general, the works of leading researchers A. Aristova, D. Gorevy, O. Gorkusha, V. Yelensky, S. Zdioruk, A. Kolodny, P. Kraliuk, O. Sagan, P. Saukh,A. Smirnov, L. Filipovich, Y. Chornomorets, A. Yurash, P. Yarotsky and others are devoted to the religious and philosophical understanding of the processes of autocephaly in Orthodox canonism.

Despite the significant scientific interest of both secular and ecclesiastical science in the chosen topic of research, the problem of autocephaly and the possibility of its provision during the Ecumenical Councils remains unsolved. In addition, the autocephalous principle of the existence of the Ecumenical Church during the formation of church canons is not covered. The presence of a number of unresolved scientific problems concerning the autocephalous structure of the Ecumenical Church in the early Christian period significantly actualizes the chosen topic.

The aim of the article is to study the autocephalous principle of the church-administrative system in the era of the Ecumenical Councils. This is the basic period of formation of church doctrine, which has not lost relevance in the XXI century. Today it is important to establish non/compliance with the mechanisms of governing the church structure, which were formed in the decisions of the Ecumenical Councils, as the highest bodies of church government. The main question of the study is whether the principles of acquiring autocephaly by the new church in the mentioned period were finally formed, and whether their application is possible in practice in the conditions of the existing system of Local Churches.

Historical and religious review shows that the early Christian period was characterized by extremely active spread of the new religion. The apostles preached "in all tongues", and the Christian martyrs testified to the truth of the new faith with thousands of their voluntary deaths and sufferings for Christ. The foundations of the doctrine and canon of the sacred books were formed. The parish network acquired a systemic distribution. The institution of the church hierarchy acquires a permanent shape. During the first three centuries of its existence, Christianity significantly expanded its church network and became widespread. Gradually, the state administrative division of the Roman Empire passed into the ecclesiastical environment. The first metropolitanates were formed and the role (spiritual and administrative) of the bishops of the capital provinces was increased. Of particular importance is the Bishop of Rome, to whom the clergy turn as the supreme spiritual court and the main instance in the interpretation of church dogmas. As for the church-administrative system, the studies of the early Christian period show that the apostles did not know and did not foresee any principle of existence of the Ecumenical Church other than autocephaly [1, p. 23].

In the first centuries of Christianity, it was the autocephalous status of the communities and entire churches founded by the apostles and their disciples that was self-evident. The autocephalous principle of the church-administrative system was a certain fact of the church arrangement itself. At the same time, the institution of the church hierarchy was clearly formed in the early Christian period. For example, when a new bishop was elected to the local chair, and he was elected from among the local faithful, i.e. it was a candidacy known to the whole community, a blessing or personal participation in the election and ordination of the chief bishop of the central city of the province was required, metropolitan [2, p. 157]. Another example, known in pre-Nicaea times, but recorded in Rule 12 of the Fourth Ecumenical Council, shows that a bishop cannot divide his diocese in two to obtain the title of metropolitan. The rule refers to the frequent abuse of Episcopal power to please secular rulers to artificially elevate the role and influence of local departments [3, p. 408].

The management of the church in the first three centuries is as follows. The main city where the bishop served, and the surrounding settlements where the elders and deacons carried 
out church obedience, in fact formed a separate church. This was a minimal autocephalous formation. Such an autocephalous diocese was governed by a bishop, but together with the clergy and laity. In the era of Ecumenical Councils and the formation of ancient patriarchates, the system of government has not changed. But the laity was no longer involved in the management of the church. Their place was taken by government officials.

After the signing of the Edict of Milan in 313, the church-administrative situation gradually changed. The epoch of the Ecumenical Councils (325-787) radically rearranged the church-hierarchical structure. From the category of "persecuted" Christianity is transformed into the category of "state" religion. In the Constantine era, being a Christian becomes an honor. The emperor began to call himself "bishop of foreign church affairs" [2, p. 371]. The new religion received wide privileges, thanks to which it quickly spread throughout the empire. But at the same time, the state is actively trying to subordinate the church to its own interests. Over the next thousand years, the church institution played a key role in shaping the overall imperial ideology. Thus, at the same time as the broad rights, the Church became dependent on state policy and the emperor. Constantine's successors participated not only in the external spread of Christianity and the arrangement of churches, but also sought to control the internal life of the church. The emperors approved the candidacies of bishops of the capital cities. Later it came to the point that the ruler could independently decide or remove the patriarchs. In disputes over dogmatic truths, the emperor could make the final own decision. The so-called "religious" decrees were formed [2, p. 372]. This determined the basic principles of church life and organization in the Council period. With the spread of Christianity and its introduction into the rank of state religion, autocephaly from the basic institution of church organization is transformed into a privileged state [1, p. 21].

As for the authority of the bishop in the diocese entrusted to him, since the Fourth Ecumenical Council he has gained full authority over parishes, monasteries and diocesan property. The bishop is considered the only full representative of his separate church (diocese) at any general councils and meetings. Nothing happened without his will. Thus, within the diocese, a strict hierarchical dependence on the local bishop was formed.

Gradually, the relations between the individual churches-dioceses were transformed. From the superiority of the honor possessed by the bishops of the apostolic chairs, there is a transition to the superiority of power. This was officially confirmed in the resolutions of the councils of the IV-V centuries, when the church power was unified with the state. The great empire was divided into separate provinces - metropolitan areas, where state power and representatives of the emperor were concentrated. Later, the church-administrative division was formed according to this model. The title of metropolitan is first mentioned in the rules of the Council of Nicaea (325). The decrees stated that the metropolitan had complete control over church life in the territory under his control. Collects and heads the councils of bishops, judges them, and most importantly - elects and ordains the local episcopate [2, p. 387]. After the Fourth Ecumenical Council (451), the capital cities received a special status of patriarchy. Although already at the First Council in 325 the role of the bishops of Alexandria, Rome and Antioch was singled out, before the Council of Chalcedon they had the same powers as the metropolitans. It was at this council that the five main departments with the patriarchal title were finally formed, which divided church administration throughout the empire. All metropolitans were subordinated to a specific patriarch, according to the state-administrative division. Only some of them were guided independently by historical conditions and traditions. Such church formations were called autocephaly. In the East it was the Church of Cyprus, and in the West - the Diocese of Milan, Aquileia, Ravenna, and especially Carthage. These are the first official autocephaly, which appear next to the five ancient patriarchates [2, p. 390]. 
Thus, in the era of the Ecumenical Councils, there are radical changes in the interior design and church management. Metropolises and patriarchates are formed according to the state model. The autocephalous church system is transformed into the predominance of the largest provinces. At the same time, referring to the period of early Christianity, we have stated that the apostles founded churches (communities) on the basis of autocephaly. This is evidenced by the $34^{\text {th }}$ Apostolic Rule, which is an invariable ecclesiastical imperative: the bishops of each nation need to know the first (main) among themselves. One nation is a one church leader. In the Greek original, the word "people" means ethnic group, i.e. nation. Thus, the apostolic rule requires that each nation know its spiritual leader [4, p. XVIII]. This indicates the autocephalous status of each nation. Each of the Christian nations is independent and self-sufficient. From the independence of the first hierarch inevitably follows the independence, that is, the autocephaly of the national church which he heads. Since the time of the First Ecumenical Council, the bishop of the capital department has been called a metropolitan with the title of bishop (metropolitan) and a certain city, such as the bishop of Alexandria (6th canon of the First Ecumenical Council). Also considered valid was the term bishop of the metropolis, i.e. metropolitan, the bishop who occupies the ancient autocephalous chair.

After the Council of Nicaea, the territorial principle of granting autocephalous status to one or another church was finally established. The church division fully corresponded to the imperial state-administrative system. Therefore, the most ancient autocephalous churches, such as Ephesus, Corinth and other provincial capitals, have disappeared from the church map. In addition, according to the state model, church-administrative units received their own names, such as the metropolis and the diocese [4, p. XIX]. The new administrative division of the church structure contradicted the ancient canons, as it violated the $34^{\text {th }}$ Apostolic Rule. Due to administrative innovations, two or three nations were united into one autocephalous church, which contradicted the apostolic decrees (denies the 34th rule of the apostles). Such a contradiction of state laws with apostolic decrees was enshrined in the most famous legal list of laws of the "Corps of Civil Law" by Justinian I.

Thus, autocephalous formations from national churches gradually transformed into multinational groups under pressure from state rulers. The former autocephalous metropolitan churches merged into powerful patriarchates, which later formed a single system of ecclesiastical administration of the "pentarchic", which was fixed in the corps of civil law of Justinian the Great. In the same document, the Patriarch of Constantinople was awarded the title of "Ecumenical". The Patriarchate of Constantinople, as the Mother Church of the "barbaric world", because the title of the Ecumenical Church meant the registration of all those who wanted the faith of Christ outside the Byzantine Empire, was entrusted with the right and duty to maintain peace and care to prevent church divisions [5, p. 149]. Thus, one way or another, all newly converted nations were to be accountable to the Ecumenical Church, at least until their own autocephalous church was proclaimed there.

The struggle in the East for influence in the ecclesiastical sphere was lost by the Patriarchate of Alexandria and Antioch. The status of the capital's department was finally enshrined in the decrees of the Council of Chalcedon. Despite the fact that the primacy of the Roman chair was formed historically, and until 1054 officially even the emperors did not question it, the Patriarchate of Constantinople never recognized the supremacy of the Bishop of Rome [6, p. 16].

The powerful Byzantine Empire, due to the vastness of the territory and the heterogeneity of the conquered population, felt a serious threat from national manifestations. Everything that threatened the centralization of power and any ethno-national formations were suppressed. A similar thing was observed in the imperial church policy. Autocephaly, church independence from 
the metropolitan patriarch was considered unacceptable. The concept of governing the whole church by five patriarchates acquired a certain mystical justification, especially in the IX and XI centuries in the works of the Patriarchs of Antioch Peter and Michael Psel [7, p. 300].

Ivan Pavlovsky, a well-known fighter for Ukrainian ecclesiastical independence in the early XX century, wrote that nationalism was an instrument for the division of the Eastern Churches. He believes that nationalist selfishness is the biggest factor in the separation of churches at any time. In this case, such a church becomes an instrument for political and state purposes, and in general it plays a divisive role for the United Ecumenical Church [8, p. 102].

In general, the topic of autocephaly was not directly raised during the Ecumenical Councils. The canons and rules of the cathedrals record the existence of autocephalous churches, which were formed under the influence of ancient departments, and especially the state power of the imperial period. Most canons do not directly use the term "autocephaly", but several fathers of that period in their works and epistles testify to the autocephalous system as the basic principle of the church's existence. For example, the district message of one of the most famous fathers of the Church of St. Cyril of Alexandria speaks of the order of church piety. St. Cyril explains that in the judgment of the bishop it is necessary to adhere to the truth in financial accountability. The first hierarch (obviously the autocephalous church) should not demand a report on the property. It is important for our study to mention the autocephalous system. The bishop is not accountable to anyone, but to his first hierarch, i.e. the chief bishop of the capital [9, p. 89].

Summing up, we note that the formation of the dogmatic-canonical system of Christianity took place in a fierce struggle for leadership (obviously for influence) between the ancient departments: Roman, Alexandrian, Antioch and Constantinople. The founding of a new capital in the city of Constantine the Great prompted the emperors, and especially Theodosius I, to build a church model on the state model. To do this, it was necessary to raise the role of the capital's patriarch [10, p. 217], who later received the title of "Ecumenical". This meant his final victory over the ancient departments of Alexandria and Antioch. The capital of Rome retained the honorable first place in the diptych until 1054, but in fact Constantinople, as the residence of the emperor, never recognized the Roman supremacy.

The problem of autocephaly did not rise directly during the Ecumenical Councils. Over time, the autocephalous, in their internal arrangement and basic principle of existence, dioceses-churches were united into metropolitanate. Several metropolises, such as Cyprus in the East and Carthage in the West, retained their autocephalous status for several more centuries (and Cyprus to this day). However, most of the church's autocephalous formations were united into powerful patriarchates, and created the so-called theory of governing the Ecumenical Church "pentarchic" (governing five churches). Mostly such unification took place under pressure from the state authorities. Byzantine emperors after the First Ecumenical Council played a significant, and sometimes decisive, role in church government. Eventually, this will significantly change the church structure and dissolve the church in the state apparatus. Thus, the period of formation of the dogmatic-canonical structure of the church, which is relevant today, does not give us an unambiguous answer to the problem of autocephaly. The rules and resolutions of the Councils only fix the existing system of church-administrative division, and do not offer any algorithm for the formation and proclamation of a new autocephalous church. On the contrary, the imperial government fights in every possible way against any national manifestations. Thus, the ambiguous coverage of the problem of autocephaly during the Ecumenical Councils leaves room for further scientific research on the issue of autocephaly systematization of Ecumenical Orthodoxy. 


\title{
References
}

1. Кобетяк А. Єдність та Соборноправність Православної церкви в контексті формування загального диптиха. Практична філософія. 2019. № 2. С. 17-24.

2. Смирнов Е. История Христианской Церкви. 2-е изд. исправл. Свято-Троицкая Сергиева Лавра, 2007. 768 с.

3. Книга правил Святых Апостол, Святых Соборов Вселенских и Поместных и Святых Отец. Москва : Изд-во святителя Льва, Папы Римского, 2010. 447 с.

4. Мулик-Луцик Ю. Історія Української греко-православної церкви в Канаді. Вінніпег : Видавнича спілка «Екклезія», 1984. Т. 1 : Київська церковна традиція українців Канади. 616 с.

5. Олександр (Драбинко), митрополит. Українська церква: шлях до автокефалії. До дискусії навколо канонічного статусу, богослужбової мови та історії Української церкви. Київ : Фонд пам'яті Блаженнішого Митрополита Володимира ; Дух і літера, 2018. $684 \mathrm{c}$.

6. Мулик-Луцик Ю. Історія Української греко-православної церкви в Канаді. Вінніпег : Видавнича спілка «Екклезія», 1987. Т. 3 : Українська греко-православна церква в Канаді в юрисдикції митр. Германоса. 728 с.

7. Поснов М. История Христианской церкви (до разделения Церквей - 1054 г.). Киев : Изд-во имени святителя Льва, Папы Римского, 2007. 614 с.

8. Ігнатуша О. Православні церкви України (20-30-ті pp. XX ст.). Джерела з історії : навчальний посібник. Запоріжжя : Запорізький національний університет, 2008. 307 с.

9. Филарет (Гумилевский), архиепископ. Историческое учение об отцах Церкви. Киев : Изд-во имени святителя Льва, Папы Римского, 2008. 533 с.

10. Саган О. Вселенське православ’я: суть, історія, сучасний стан. Київ : Світ знань, 2004 $912 \mathrm{c}$.

\section{КАНОНІЧНИЙ ПРИНЦИП АВТОКЕФАЛЬНОСТІ В ПОСТАНОВАХ ВСЕЛЕНСЬКИХ СОБОРІВ}

\author{
Андрій Кобетяк \\ Житомирський державний університет імені Івана Франка, \\ кафедра філософії та політологіi \\ вул. Велика Бердичівська, 40, 10008, м. Житомир, Україна
}

\begin{abstract}
У статті проаналізовано вплив Вселенських соборів на історико-правові аспекти проголошення автокефалії й автономії церкви як об’єкт дослідження. Встановлено, що в до соборний період вчення Христа й апостолів передавалось переважно через проповіді святих отців. Відсутність зафіксованого канону, догматів спричинила зародження перших теологічних дискусій, пов'язаних зі ставленням до Церкви, Святого Письма та християнського вчення. Доведено, що саме в період Вселенських соборів уся догматично-канонічна творчість ранньої Церкви була оформлена в конкретні правила у вигляді постанов Соборів.

Уважаємо, що Вселенський собор був реакцією всієї Церкви на певну проблему, з якою церковний загал раніше не стикався. Це панацея для того, щоб вилікувати певну рану на церковному тілі, яка виявляла себе в упередженості чи викривленому тлумаченні окремих місць Святого Письма. Отці та представники всіх тогочасних помісних церков збирались разом для соборного вирішення проблеми, яка турбувала Церкву. Встановлено, що в цей період було остаточно закріплено в постановах Другого й Четвертого Вселенських соборів автокефальний принцип існування окремих церков, який був запозичений із Візантійсько-Римської імперії. Доведено, що найвищим рівнем церковної організації стають древні патріархати, які об'єднували кілька митрополій. Формується
\end{abstract}


«пентархія», теорія управління Вселенською церквою п’ятьма найвпливовішими кафедрами. Така структура адміністративно-церковного розподілу у структурі Вселенської церкви зберігається і нині. Кожна з помісних церков, незалежно від статусу, самостійна у власному внутрішньому житті.

Ми вважаємо, що приклад вирішення церковних суперечок та боротьби із церковними розділеннями в період Вселенських соборів необхідно використати сучасним ієрархам. Нині Вселенська церква перебуває на межі великої схизми. Кілька помісних церков розірвали Євхаристичне спілкування, яке символізує загальну єдність. Тому подальші детальні дослідження нікейського періоду й інституалізація автокефального церковного устрою того часу слугуватимуть налагодженню толерантного діалогу між ієрархами помісних церков у XXI столітті.

Ключові слова: Вселенський собор, патріархат, диптих, автокефалія, канон, митрополит, політичний вплив. 